\title{
Consequence of oil and Waste Spills on the Environment of Ogoniland, Rivers State, Nigeria
}

\author{
Amosu C.O., Adeosun T.A.
}

\begin{abstract}
: environmental degradation of the oil-rich niger delta region has been wanton and continuous with dire health, social and economic consequences for its peoples, for over three decades. Oil exploration and exploitation is very lucrative, and a major revenue earner in nigeria. But, like most industrial activities, it produces environmental hazards that are "slow poisons," in that they often take months and years to cause disease and death. This is unlike the contamination of water, food, and the environment with micro-organisms, which immediately results in ill health. The covert and slow action of the hazards created by oil exploration and exploitation make it difficult to fully appreciate their contribution to the disease burden in nigeria, especially in the oil-bearing communities, even with the emergence of non-communicable diseases as major causes of ill health in nigeria. This paper addresses questions like: what challenges and impact will ogoniland face concerning spillage of oil and other wastes on its environment (water, vegetation, aquatic lifes, people and socio-economic lifes? Which are the spillage control measures to be adopted in ogoniland to obtain best production culture and consideration? It discusses the trend of oil spillage problem and possible antidote to it in the niger delta part of nigeria.
\end{abstract}

Keywords: Spill, Ogoniland, Environment, Oil, Metallic, Contamination, Niger-Delta, Degradation, Nigeria.

\section{INTRODUCTION}

$\mathrm{A}_{\mathrm{n}}$ oil spill is an accidental pollution of the release of liquid petroleum hydrocarbon into the environment due to human activity, and is a. Oil spill can be on land where its impact can easily be eliminated. However, marine oil spills can result in oil pollution and causes serious environmental hazards, which lead to serious ecological risk and long term environmental disturbances. The major sources of oil spillages into the sea are associated with oil transportation by tankers and pipelines. Large number of oil spills happened as a result of accidents of the tanker carrying the crude oil. When marine oil spill happened, it usually causes immediate harm to the entire environment and living organisms present. Other consequences of the oil spill will follow after long period of time. Different species of fish and sea mammals, oysters, crabs, shrimps, turtles and indigenous flora and fauna gradually as a result of changes in the chemical composition of the water (habitat) and physical alteration of the habitat (Neff, 2002).

\footnotetext{
Manuscript received on 28 March 2021 | Revised Manuscript received on 04 April 2021 | Manuscript Accepted on 15 October 2021 | Manuscript published on 30 October 2021.

* Correspondence Author

Engr. Amosu C.O*., Department of Mineral and Petroleum Engineering Yaba College of Technology, Yaba. cyril.amosu@yabatech.edu.ng

Adeosun T.A. Department of Mineral and Petroleum Engineering Yaba College of Technology, Yaba. tunde.adeosun@yabattech.edu.ng

(c) The Authors. Published by Lattice Science Publication (LSP). This is an open access article under the CC-BY-NC-ND license (http://creativecommons.org/licenses/by-nc-nd/4.0/)
}
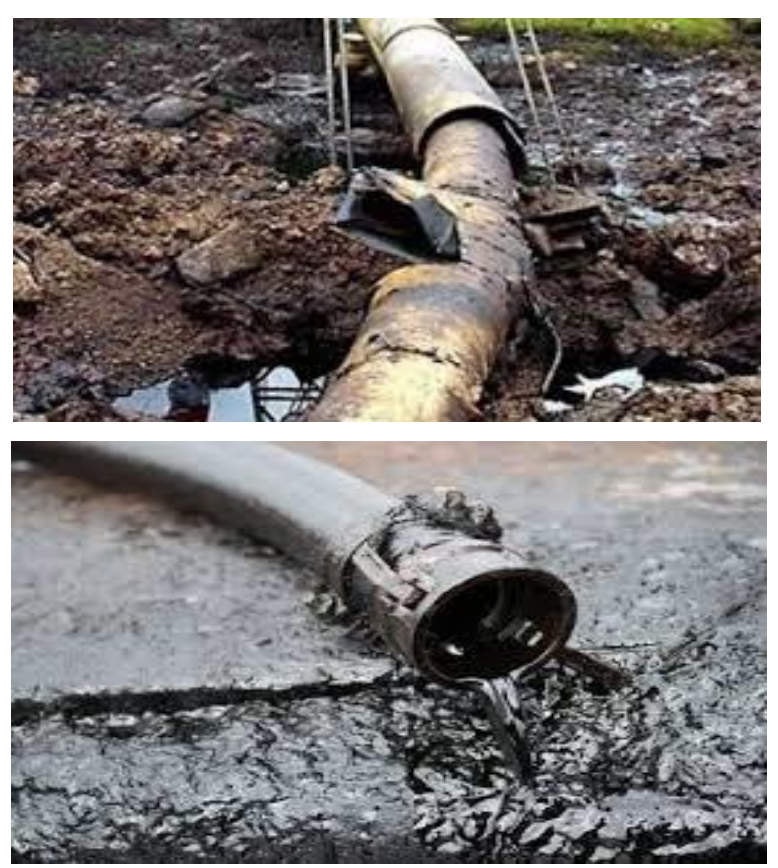

Figure 1: Iinstances of Oil Spill Incidence in The Niger Delta of Nigeria (Source: energymixreport.com and steemit.com)

\section{CAUSES OF OIL SPILLAGE IN NIGERIA}

Oil spillage in Nigeria can be:

(a) Natural causes , i.e. shift of tectonic plates and inadequate trap system

(b) Inadequate trap system causes, i.e. faults, conformities

(c) Man-made causes i.e.vandalisation of oil pipes, workers carelessness (tanker drivers, oil bunkering, sabotaging and oil siphoning)

(d) Mysterious causes, i.e. unknown forces or causes

\section{ENVIRONMENTAL CONSEQUENCES OF SPILLAGES POLLUTION OF WATER RESOURCES}

Hydrocarbons can enter water through direct spills or from a spill originally occurring on land and subsequently reaching water bodies through the effects of wind, rain, surface or sub-surface flow. Hydrocarbons can cause both physical and chemical effects in water; even at very small quantities, it affects aquatic life-support systems. The presence of mere traces of a highly toxic hydrocarbon, such as benzene, may render water unfit for human consumption (UNEP, 2013).

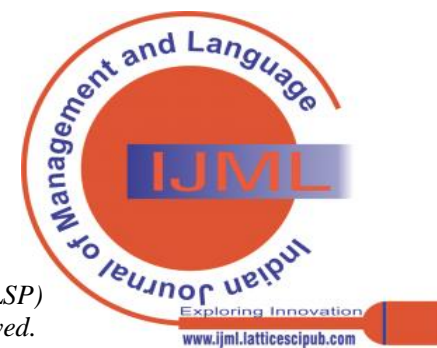




\section{Impact of Gas Flaring}

Between 1970 and 2004 Nigeria has flared an average of $76 \%$ of the total gas produced. Much of the natural gas extracted in oil wells in the Niger Delta is immediately flared into the environment at a rate that approximates 70million /m3 per day. (Emoyan, AkpoborieandAkporhonor
, 2008). According to Ite and Ibok (2013), gas flaring and venting associated with petroleum exploration and production in the Nigeria's Niger Delta has continue to generate complex consequences in terms of energy, human health, natural environment, socio-economic environment and sustainable development over the past fifty years.

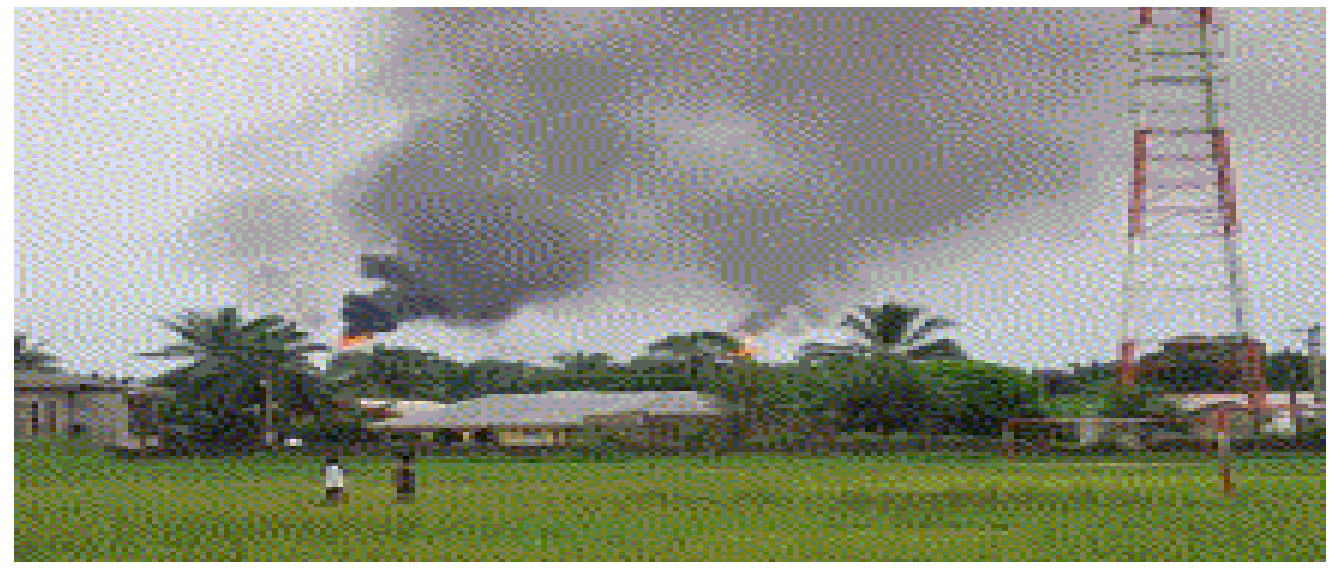

Figure 2: Impact of Gas Flaring in Ogoniland (Source: Christopher, 2017)

\section{Impacts On Soil}

Excessive exploration and seismic activities have negative consequences for soil toxicity and the quality of crops. There is a general concern by environmentalists that the quality of crops in the Niger Delta is rapidly deteriorating. The quality, size and shape of traditional staples such as cassava, yam, plantain, and so on which are adversely affected by the continuing forage for oil without the requisite Environmental Impact Assessment (EIA) (Akpomuvie, 2011).

\section{Impacts On Water}

Groundwater evaluation is increasingly tilting toward a watershed approach due to large-scale contamination, resulting from urban development, rapid population growth, and land use changes (Ophori, 2006). Contamination of controlled water sources in the Niger Delta have made the people to resort to drilling borehole for drinking water, therefore, the protection of groundwater supply is importance to help mitigate potential risks associated with petroleum contamination.

\section{Impacts On Vegetation}

The toxicity of the spill is demonstrated by the fact that a test showed that $96.5 \%$ of the mangrove seedlings among other plants on the shoreline died within fourteen days of exposure to oil film. (Aghalino and Eyinla, 2009)

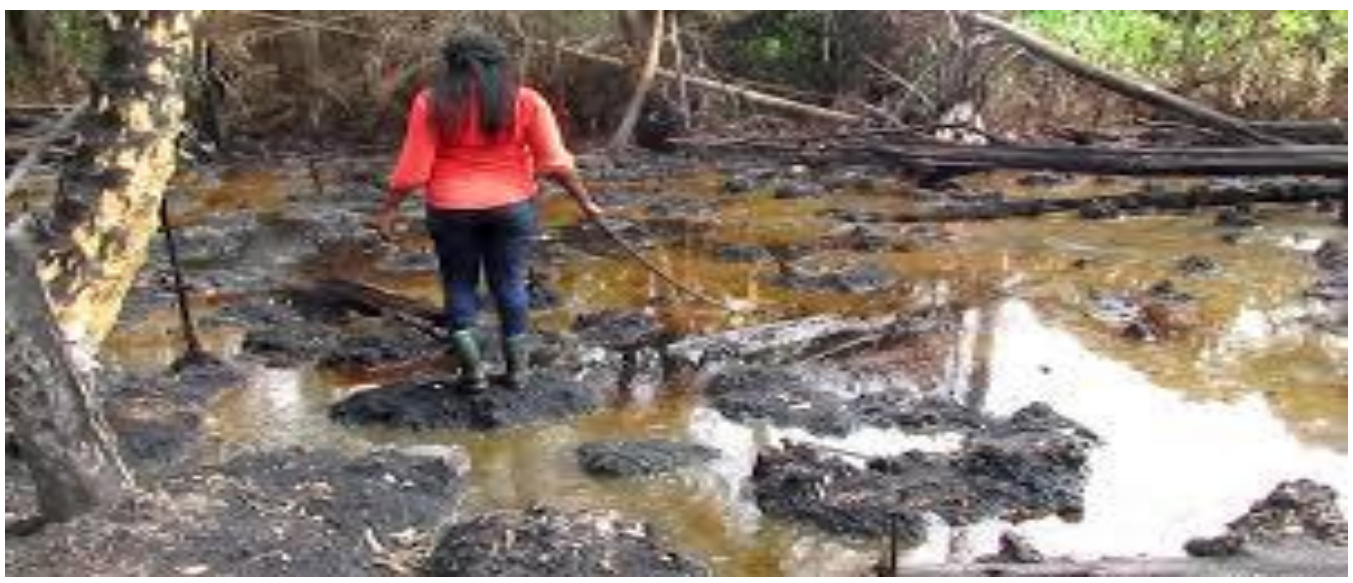

Figure 3: Impact of Oil spill pollution on vegetation in Ogoniland (Source: farn.org)

\section{Impacts On Aquatic and Terrestrial Wildlife}

Mangrove ecosystems are a shelter for biological diversity consisting of diverse aquatic and terrestrialflora and fauna which include mammals (monkeys, antelopes, and manatees), molluscs (bivalves, oysters), crustaceans, fish, reptiles and avian species.

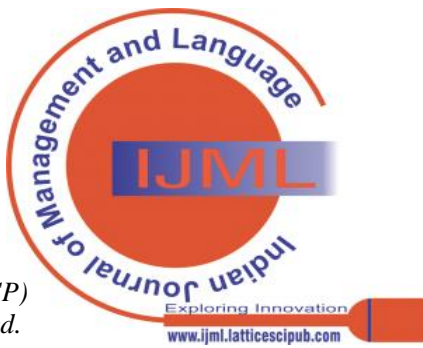



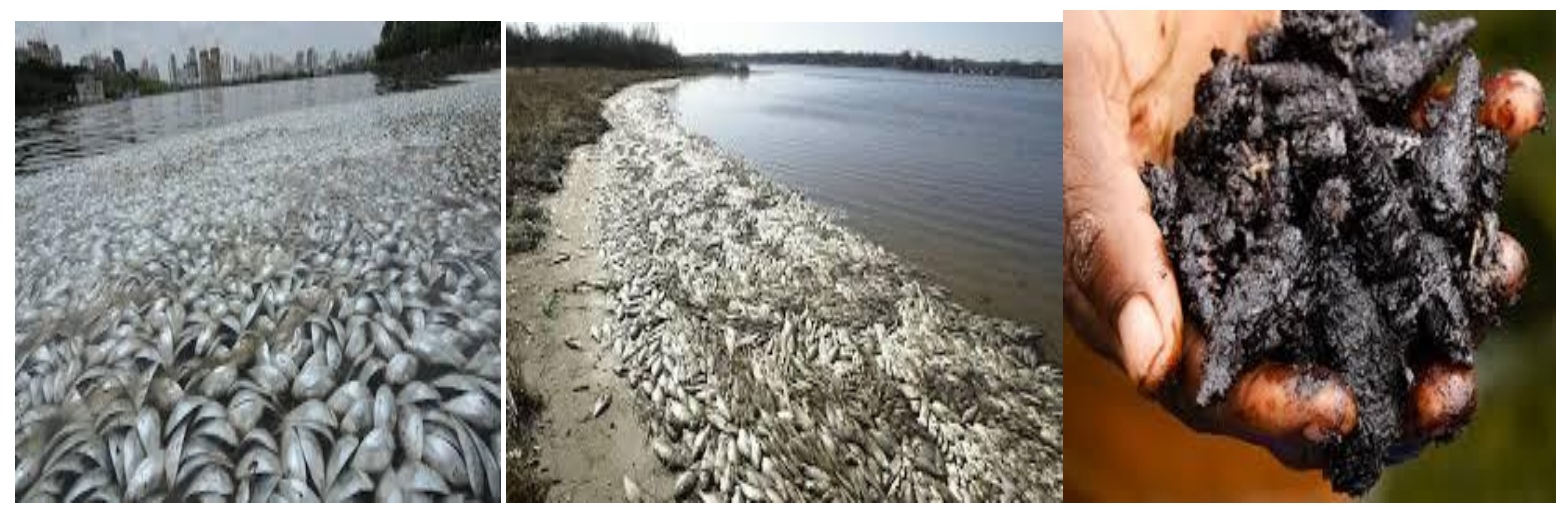

Figure 4: Impact of Oil spill pollution on the aquatic environment in Ogoniland

(Source: akahinews.org, environewanigeria.com and fairplanet.org)

\section{Impacts On People}

Petroleum hydrocarbons can enter people's bodies when they breathe air, bathe, eat fish, drink water or accidentally eat or touch soil or sediment that is contaminated with oil. Acute health effects of exposure to petroleum are reasonably well understood: dermal exposure can lead to skin redness, oedema, dermatitis, rashes and blisters; inhalation exposure can lead to red, watery and itchy eyes, coughing, throat irritation, shortness of breath, headache and confusion; and ingestion of hydrocarbons can lead to nausea and diarrhoea (UNEP, 2013).

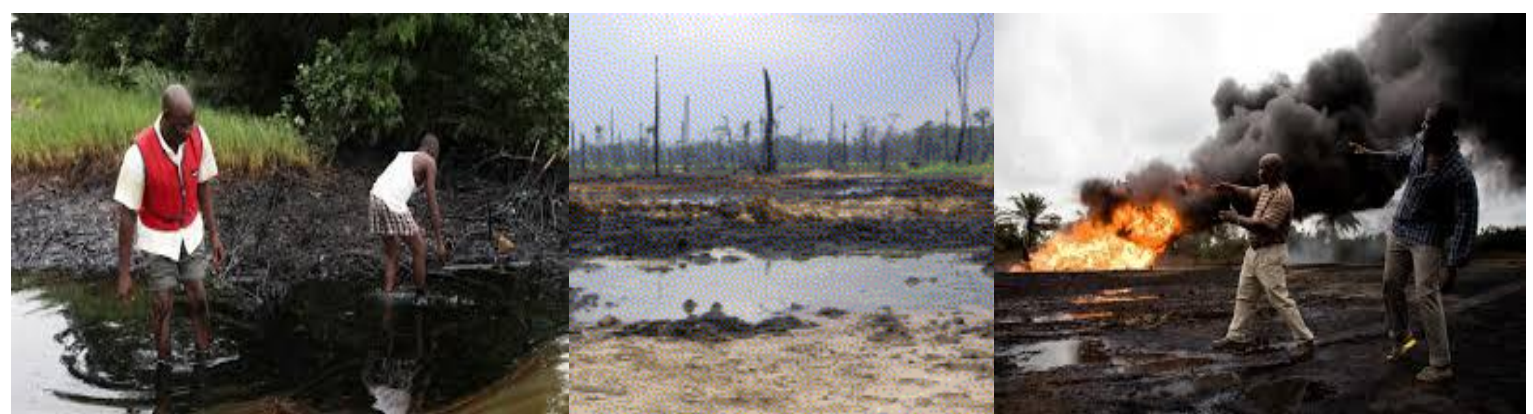

Figure 5: Impact of Oil spill pollution on the dwellers in Ogoniland (Source: Christopher, 2017).

\section{Impacts Of Specific Hydrocarbons On} Environment And Health

As pollutants, they are of concern because some compounds have been identified as causing cancer, changing genetic structures and affecting embryos and foetuses (UNEP, 2013).

\section{Non-Hydrocarbon Environmental Issues} Related To The Oil Industry
In addition to chemical pollution by hydrocarbons, there are other environmental concerns linked with oil industry operations. These range from clearance of land for oilfield facilities, hydrological changes due to construction of roads and pipelines, and contamination from chemicals other than hydrocarbons.

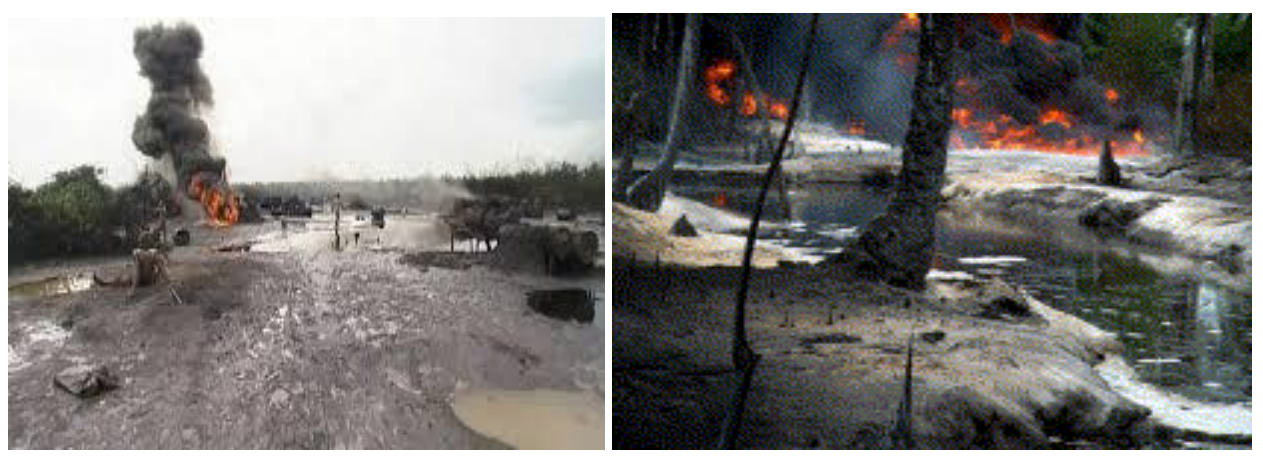

Figure 6: Impact of Oil spill pollution directly from operation of Oil companies in Ogoniland (Source: Britannica.com and Christopher, 2017)

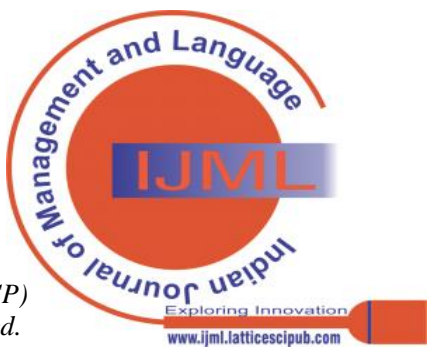




\section{Gross Socio-Economic Underdevelopment}

Enormous money had been derived from oil export but the area has been subjected to severe land degradation, socioeconomic disorganization, increasing poverty, misery, military occupation and bloody violence (Ibama and Eyenghe, 2015). Oil extraction has impacted most disastrously on the socio-physical environment of the Niger Delta oil bearing communities massively threatening the fragile subsistent peasant economy. Aquatic life has also been destroyed with the pollution of traditional fishing grounds, exacerbating hunger and poverty in fishing communities (Pittocket al., 2018).

\section{Conflicts Between Oil Companies And Host} Communities

The deprived peasants currently make demand for social services from the oil companies, than they can make from the often-inaccessible Nigerian State. This has often led to conflict as the oil companies are engaged in the process of collaborating with the Nigerian regime to use violence as a means of pacifying the protesting communities (Ibama and Eyenghe, 2015). The activities of the aggrieved youths, in the form of pipeline vandalization, oil bunkering, piracy, hostage taking and inter-community hostilities, have often provoked counter-violence of a more destructive type from the country's security forces which has led to the loss of many lives and properties. For instance, it has been estimated that more than 2,500 oil spillages occurred in Ogoniland alone between 1986 and 1991. Although the oil companies do not deny the occurrences of oil spillages, they often blame the incidents on sabotage by local communities (Thomas, 2004).

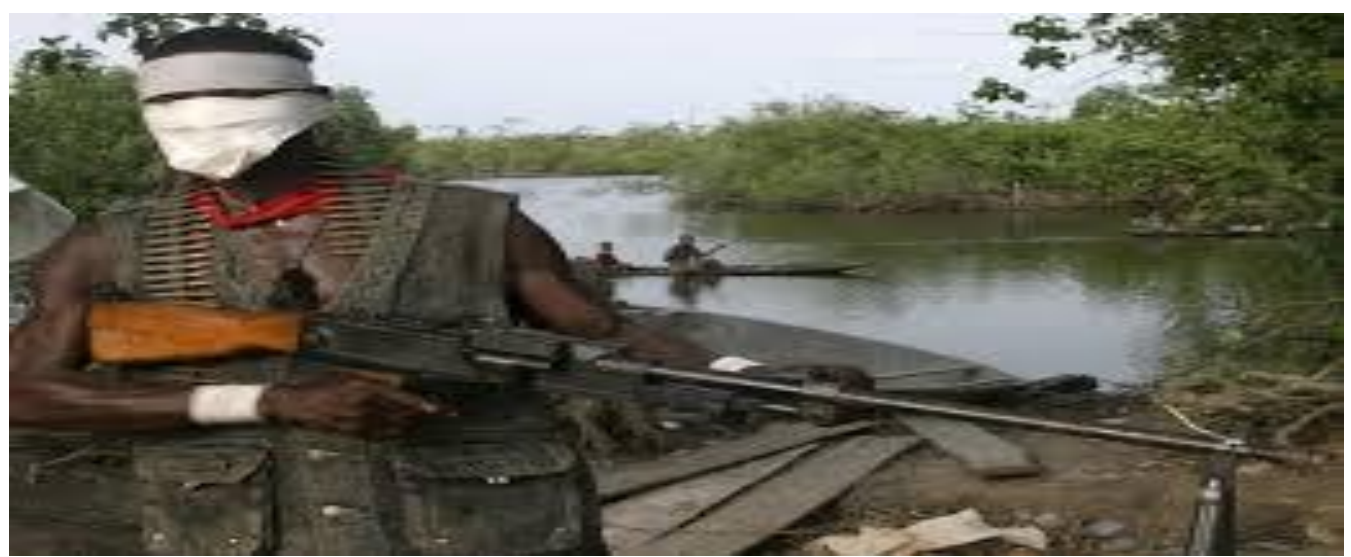

Figure 7: Impact of Oil spill pollution leading to militancy in Ogoniland (Source: qz.com)

\section{Intra And Inter-Community Conflicts}

Bitter and bloody conflicts between emerging interest groups within and between communities ranges between elite groups and between youth organizations on one hand, between the urban resident elite and the village community resident on the other scale(Ibama and Eyenghe, 2015). Among the violent inter-community or inter-ethnic confrontations in the Niger Delta are Ogoni-Adoni, OgoniOkrika, Kalabari-Brass, Bille-Ke, Ijaw-Itsekiri and ItsekiriUrhobo. The situation is such that more lives have been lost, more destruction to property has occurred and more misery has been caused to the people of the region (Thomas, 2004).

\section{MANAGEMENT OF OIL SPILL IN NIGERIA}

Several laws and policies have been taken in managing oil spill incidents at the international and national levels. These laws and policies are given in the following sections:

\section{Oil Pollution Act (Opa) Of 1990}

provides guidance for government and industry on oil spill prevention, mitigation, cleanup and liability.

Provides targets at reducing the number of spills followed by reducing the quantity of oil spilled. ensures that sufficient financial resources are available to clean up a spill and to compensate persons damaged by a spill.

ensures that the federal response system is adequately prepared to manage the impacts of oil spills that do occur; mandates industry implement prevention and preparedness measures.

mandates tankers and inland oil facilities to develop individual response plans.

mandates enhancements to the national response system, and development of Area Contingency Plans. National Oil Spill Detection and Response Agency (NOSDRA).

ensures the use of environmental-friendly drilling fluid and mud systems (Alexandra Gas and Oil Connections, 2006). The Niger Delta Development Commission (NDDC). To reduce the rate of oil incidents along the Nigerian Coast particularly as a result of vandalisation, the Federal Government through an act of the National Assembly in 2000 passed into law the Niger Delta Development Commission (NDDC).

\section{Petroleum Related Laws And Regulations}

Part of the means of managing the environment is to have in place the necessary laws, regulations and guidelines. According to the Federal Environmental Protection Agency, Lagos Nigeria, the following relevant national laws and international agreements are in effect:

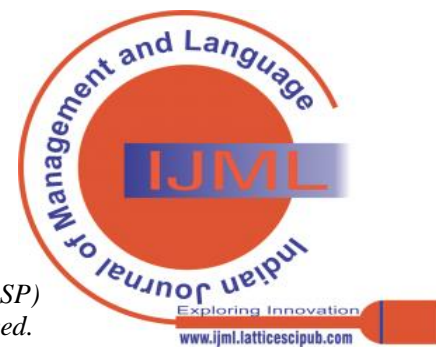


a) Endangered Species Decree Cap 108 LFN 1990.

b) Federal Environmental protection Agency Act No.58 of 1988 (Ibaba, 2010).

c) Harmful Waste Cap 165 LFN 1990.

d) Petroleum (Drilling and Production) Regulations, 1969 (Ibaba, 2010).

e) Mineral Oil (Safety) Regulations, 1963.

f) Associated Gas Re-injection Act 1979 (Ibaba, 2010).

g) International Convention on the Establishment of an International Fund for Compensation for Oil Pollution Damage, 1971

h) Convention on the Prevention of Marine pollution Damage, 1972

i) African Convention on the Conservation of Nature and Natural Resources, 1968

j) International Convention on the Establishment of an International Fund for the compensation for Oil Pollution Damage, 1971.

k) National Policy on the Environment in 1989

l) Oil pipelines Act Cap 145 LFN 1990 (Gabriel, 2013).

III. The Environmental Impact Assessment (Eia) Decree No 86 Of 1992

The Environmental Impact Assessment (EIA) decree No 86 of 1992 was promulgated to:

protects and sustain our ecosystem.

makes the development of an EIA compulsory for any major project that may have adverse effects on the environment.

\section{Creating Of Awareness}

Awareness creation on the impacts of oil spill is an integral part of management programme for oil spill along the coast of Nigeria. This is being carried out by government at different levels and agencies such as the Niger Delta Development Commission (NDDC).

\section{Bioremediation Oil Spill Clean-Up}

It is a biological treatment method that is used in certain oil-contaminated environments during which microorganisms usually bacteria, algae and fungi, feed on the contaminants (Ogidiand Njoku, 2017).

Examples include

a) Bacteria like Achromobacter, Arthrobacter, Acinetobacter, Brevibacterium, Corynebacterium, Flavobacterium, Candida, cyanobacteria .

b) Algal like Chlamydomonas specie, Coccochloris specie, Cylindretheca specie.

\section{Corporate Social Responsibility}

Corporate social responsibility connotes the commitment of companies towards encouraging community growth and development and voluntarily eliminating practices that are not in accordance with public interest. It is thus the deliberate inclusion of public interest into corporate decision making (Kelly et al, 2012).

\section{LITERATURE REVIEW}

About $97 \%$ of the country's foreign exchange earnings in oil and gas and $79.5 \%$ of the federal revenue are from this sector (Amnesty, 2009). The presence of Shell Petroleum Development Company (SPDC) in Ogoniland for over 50 years had destroyed the entire ecosystem (Mmon and Igbuku, 2015). The operations of shell in Ogoni community truncated the family and other traditional value system of the people (Arisukwu and Kennedy, 2012). Oil Production in Ogoni was stopped abruptly since 1993 till date as a consequence of the Ogonis agitation and protest against the Federal Government of Nigeria for alleged environmental degradation and political alienation (Ogidiand Njoku, 2017). Although, the entire country is known to benefit from the revenues generated from oil and gas production, the story is surprisingly different for the oil producing communities in the Niger Delta region (Odoemene, 2011). It is important to start removing oil promptly from contaminated areas because as time passes and the oil weathers, it causes more damage to the resources in its path (Okereke, Ogidi and Nwachukwu, 2014). In an environmental impact assessment study, Kponeeet al, (2015) focused on the community of Ogale (part of Ogoniland) located in the Eleme Local Government Area of Rivers State - Nigeria, where UNEP discovered a substantial leakage from an abandoned section of a pipeline carrying refined oil. The Ogoni people believed that the full implementation of the United Nations Environmental Programmes (UNEP) report on Ogoniland and the Ogoni Bill of Rights will ameliorate all their sufferings (Tombari, 2019). Ogoni land like most part of the Niger Delta of Nigeria, where offshore and onshore drilling is common, there are bound to be spills from wells and transporting mishaps from which oil may spread to form a surface film (Ibama and Eyenghe, 2015). The ogoni people are very knowledgeable on the environmental consequences of pollution to their environment and their health, but they are basically indigenous people and cannot move away from their communities because of pollution; rather they want to stay and fight for their freedom (Tombari , 2018). The Niger Delta is dying (Akachi, 2011).

\section{MATERIAL AND METHODS}

The literature review of the consequence of oil spill and wastes in the Ogoniland location was covered in this paper. This research adopted comparative study method which involved obtaining data from past and present studies and existing literature (Arisukwu and Kennedy, 2012; Ibama and Eyenghe, 2015; Amadi and Wegwu, 2017; Enegide and Chukwuma, 2018). The study relied on secondary data obtained Journals and the internet. The data obtained was analysed using quantitative and descriptive method and from the analysis, logical deductions and sequential presentation of facts from the data obtained. The analysis will give a clear picture of the problem and trends.

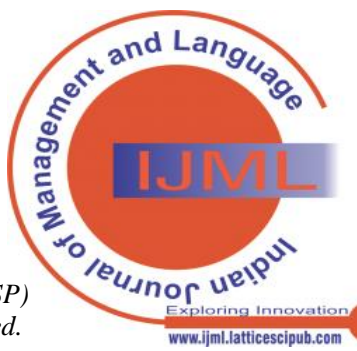




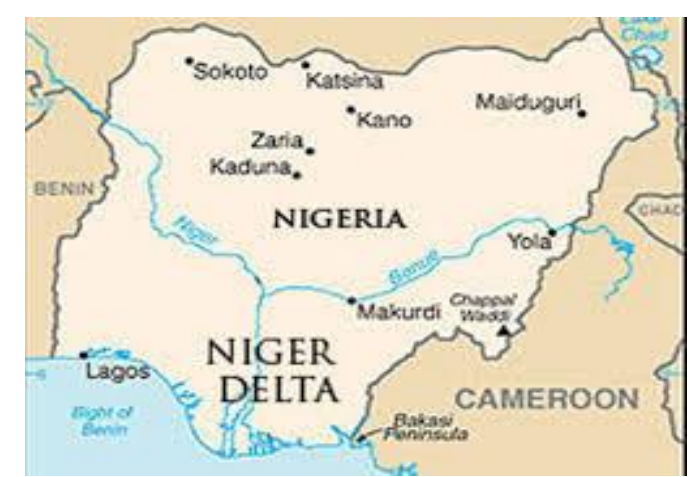

Figure 8: Regional Map of the Niger Delta Oil Producing

\section{GEOLOGY OF OGONI OIL FIELD}

It is a region in Niger Delta covering $1000 \mathrm{~km}^{2}$ in the south-east of the Niger Delta basin. It is situated on latitude $4^{\circ} 40^{\prime}{ }^{\prime}{ }^{\prime} \mathrm{N}$ and $4^{\circ} 43^{\prime} 19.55^{\prime} ' \mathrm{~N}$ and longitude $7^{\circ} 22^{\prime} 53.7^{\prime}{ }^{\prime} \mathrm{E}$ and $7^{\circ} \quad 27^{\prime} 9.8^{\prime \prime} \mathrm{E}$ (Nkaa, Amadi and Wegwu, 2017).Ogoniland has one aquifer, which is been tapped by shallow wells and deeper boreholes (UNEP, 2011).

There are five major oil fields, 110 oil wells, five flow stations and network of interconnecting pipelines across the length and breadth of Ogoniland. Natural gas considered as wastes are continually flared 24 hours a day and seven days a week for many years in all flow stations. The 404mile2 land area has population density of 1250mile, (DPR, 2007). Ogoni is a tropical wetland in the Niger Delta covering an area approximately $1,000 \mathrm{~km}^{2}$ and occupies about $1 \%$ of the Niger Delta total land area, less than $2 \%$ of the Niger Delta population ( Mmom and Igbuku, 2015). They live in closeknit rural communities, their livelihoods based on

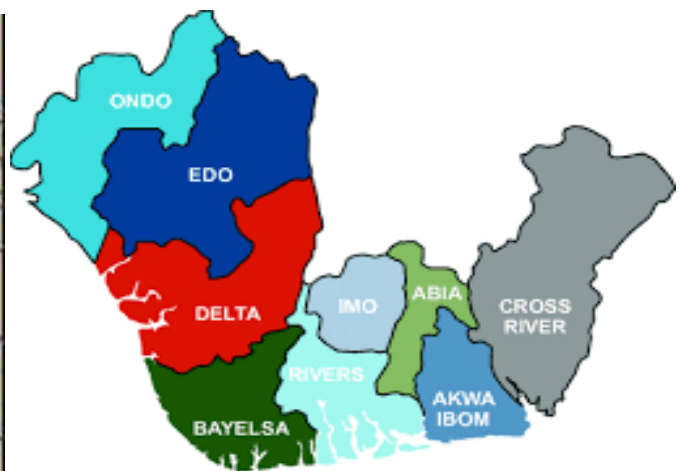

agriculture and fishing. The total population of the four local government areas (LGAs) - Eleme, Gokana, Khana and Tai - according to the 2006 National Census was 950,532 (comprising 218,200; 261,570; 336,267 and 134,495 respectively) (Tombari B, 2018).

This scope of this study targets the Ogoni Land. It sought to establish the impact of exploitation and extraction on the physical environment of the communities in Ogoni land; to review the extent of its environmental degradation and to propose best control methods using literature review. It suggests beneficial means of control and hence provides clues to preserve the environment through them. It significantly aims to address the consequences of oil and waste spillages which will contribute its quota to sustainable policy-making at the industry level. Its limitation however are proximity, time and insufficient information from the internet. Researchers chose to study the consequences of oil and waste spillages and it impacts on the environment.

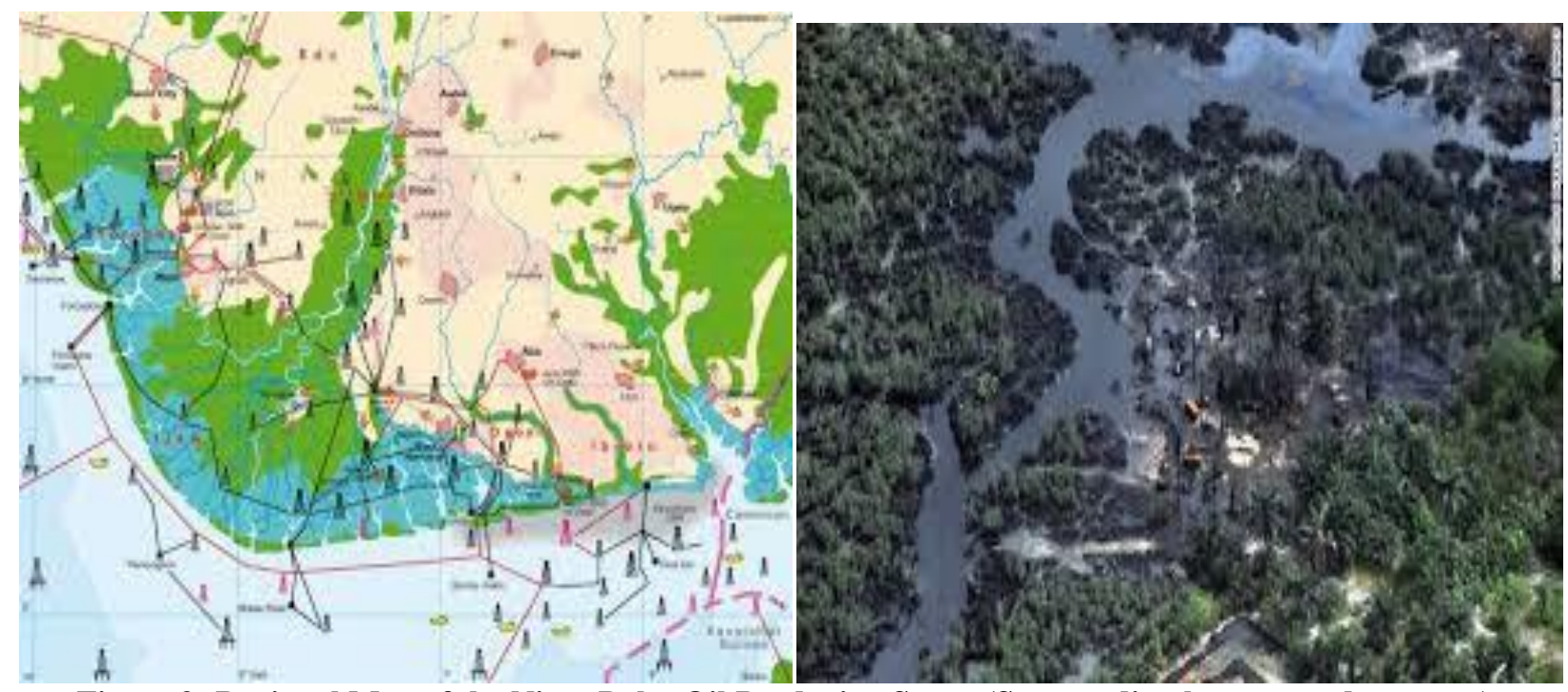

Figure 9: Regional Map of the Niger Delta Oil Producing States (Source: diercke.com. and cnn.com).

\section{DATA AND METHODOLOGY}

Victoria (2013) analysed environmental samples comprising soils and surface water for hydrocarbon content using Gas Chromatographic method and he confirmed the presence of Total Petroleum Hydrocarbons (TPH) and Polycyclic Aromatic Hydrocarbons (PAH) which are well above the Department of Petroleum Resources (DPR) target limits. See the table of his findings.

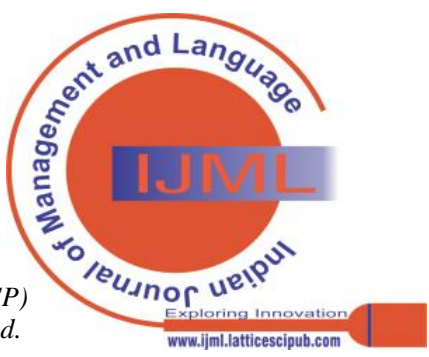


Table 1: Mean of the TPH, PAH and DPR Standards

\begin{tabular}{|c|c|c|c|c|c|}
\hline Samples & Location & TPH & $\begin{array}{l}\text { DPR } \\
\text { Standards } \\
\text { For TPH }\end{array}$ & PAH & $\begin{array}{l}\text { DPR } \\
\text { Standards } \\
\text { For PAH }\end{array}$ \\
\hline & & \multicolumn{2}{|l|}{$\mathrm{mg} / \mathrm{kg}$} & \multicolumn{2}{|l|}{$\mathrm{mg} / \mathrm{kg}$} \\
\hline \multirow[t]{2}{*}{ Soil } & Biara & 1652.7747 & 50 & 468.5365 & 1 \\
\hline & Bodo & 985.6900 & 50 & 292.3265 & 1 \\
\hline \multirow[t]{2}{*}{ Water } & Biara & 272.6871 & 30 & 87.6129 & 0.1 \\
\hline & Bodo & 48.5018 & 30 & 2.5512 & 0.1 \\
\hline
\end{tabular}

(Source: Victoria, 2013)

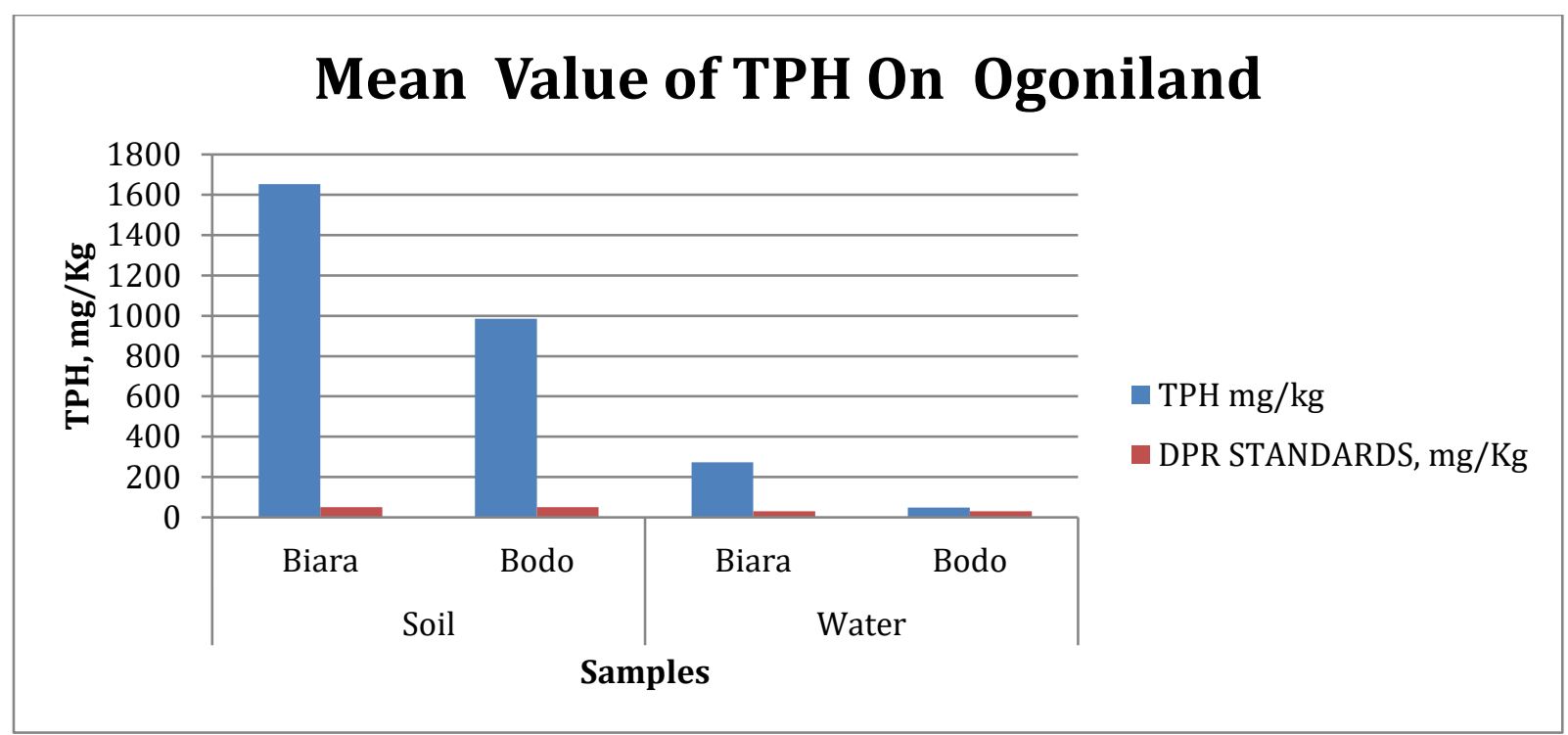

Figure 10: Mean Value of Total Petroleum Hydrocarbons (TPH) On Ogoniland.

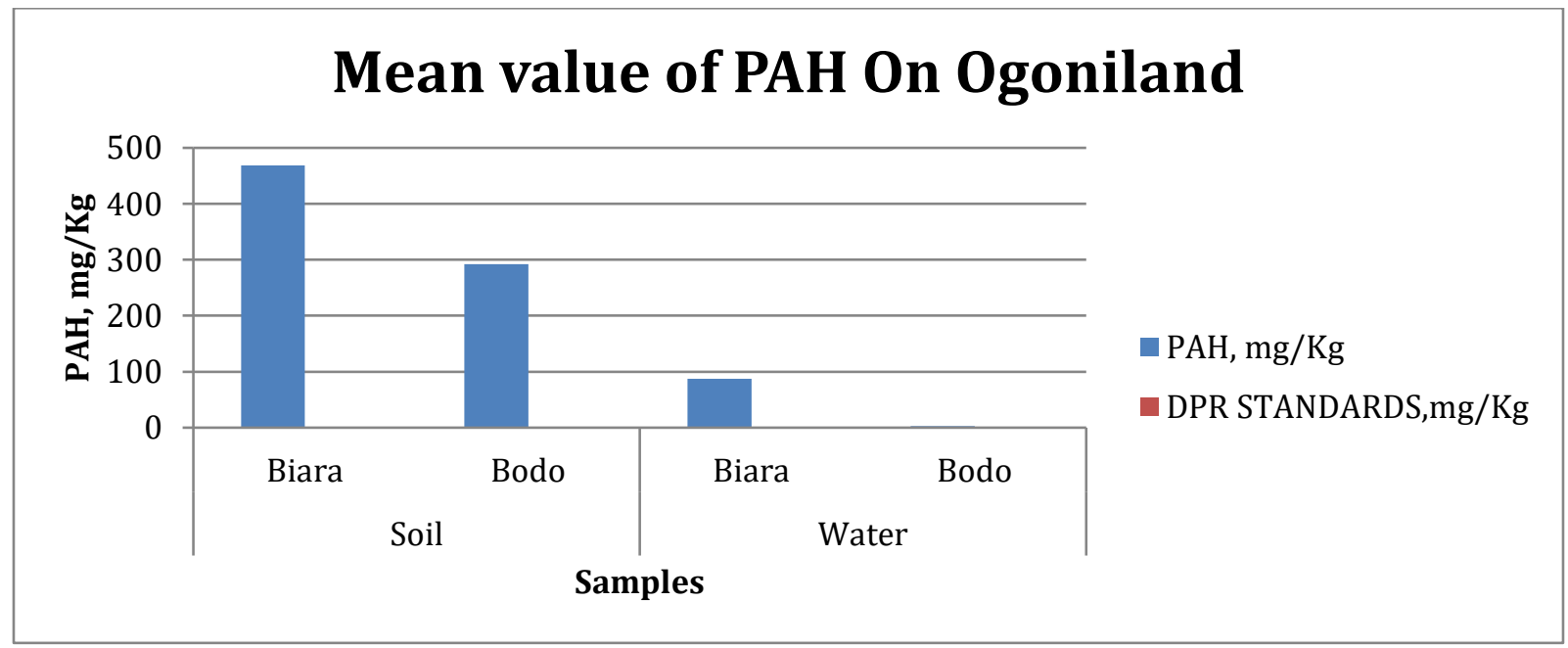

Figure 11: Mean value of Polycyclic Aromatic Hydrocarbons (PAH) On Ogoniland.

Arisukwu and Kennedy (2012) conducted studies in six component compounds of Ogoni Local Government Area of Rivers state in which he used quantitative and qualitative instruments like Questionnaire, Observation, In-depth Interviews, Case study and secondary sources of data (documents and reports) to collect and analyse data. His findings are shown as:

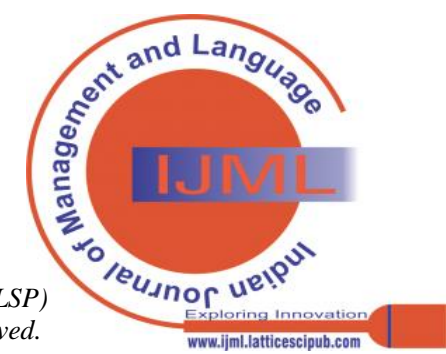


Table 2: Response of People to hazards suffered from shell operations in Ogoniland.

\begin{tabular}{|l|l|l|}
\hline Responses & Frequency & Percentage \% \\
\hline Yes & 241 & 87 \\
\hline No & 29 & 10.46 \\
\hline Don't know & 7 & 2.52 \\
\hline Total & 277 & 100 \\
\hline
\end{tabular}

(Arisukwu and Kennedy, 2012).

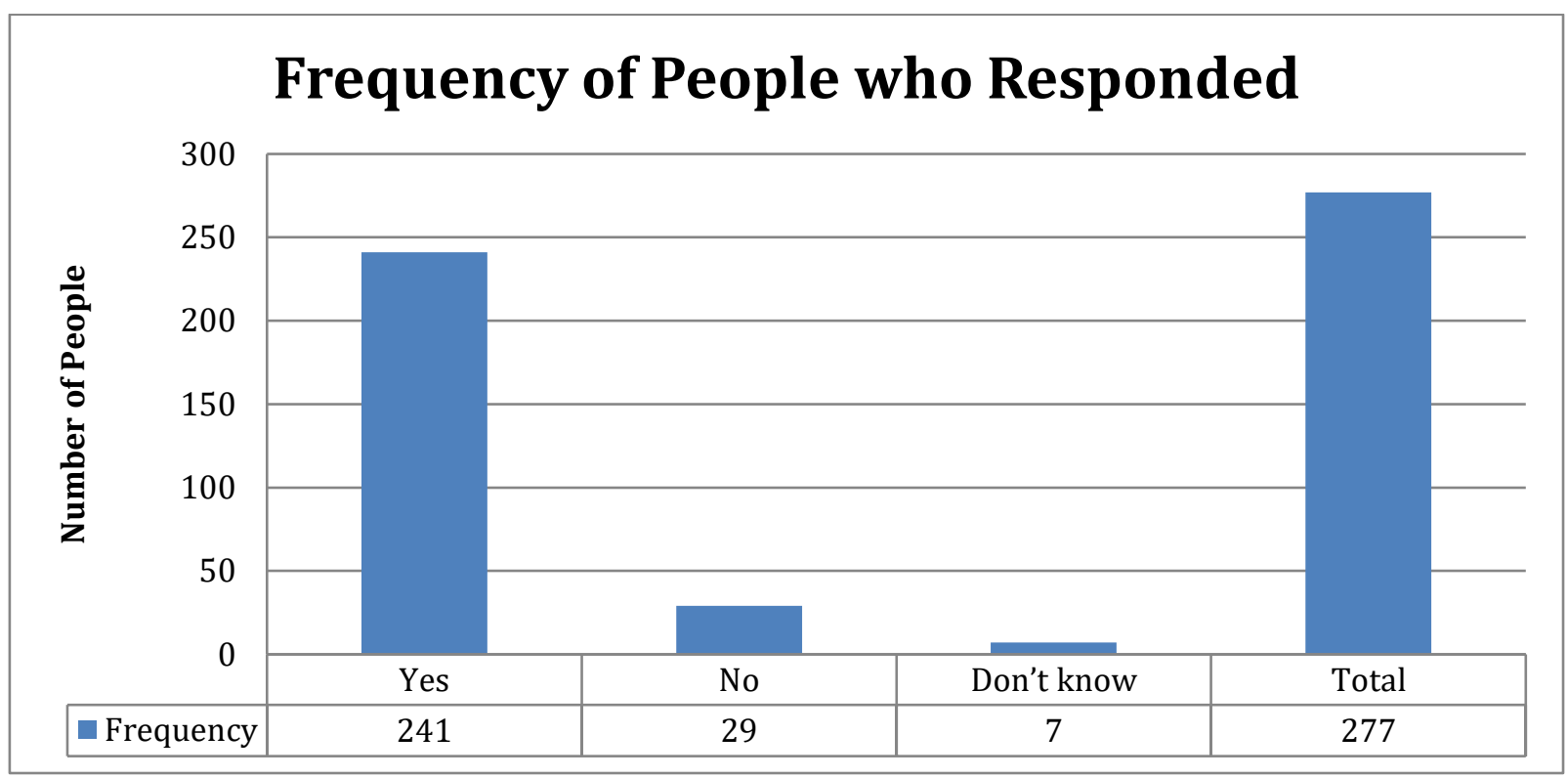

Figure 12: Frequency of People who responded to hazards suffered from Shell operations on Ogoniland in Table 2.

\section{Percentages of People who Responded , \%}

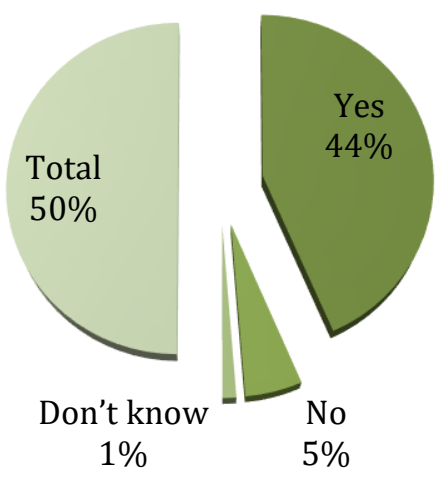

Figure 13: Percentages of People who responded to hazards suffered from shell operations on Ogoniland in Table 2.

Ibama and Eyenghe (2015) did a study to examine the impact of intensive resource exploitation on the social environment of the oil producing communities in Ogoni land using two sampling techniques which are Multi-stage Sampling technique and Simple random sampling technique. His findings are shown below:

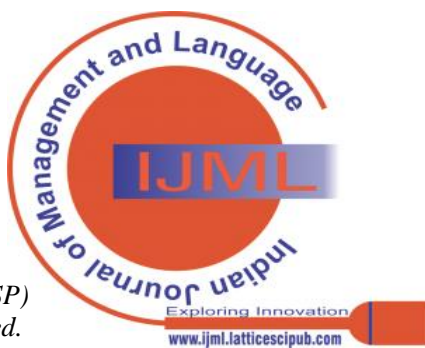


Table 3: the Impact of Intensive Resource Exploitation on the Social Environment of the Oil Producing Communities in Ogoniland.

\begin{tabular}{|l|l|l|l|l|l|l|l|}
\hline S/N & $\begin{array}{l}\text { Aspect of the Social } \\
\text { Environment(social } \\
\text { Sensitivities) }\end{array}$ & $\begin{array}{l}\mathbf{1} \\
\text { Very } \\
\text { severe, } \\
\%\end{array}$ & $\begin{array}{l}\mathbf{2} \\
\text { Severe, } \\
\%\end{array}$ & $\begin{array}{l}\mathbf{3} \text { Don't know/ } \\
\text { Uncertain, \% }\end{array}$ & $\begin{array}{l}\mathbf{4} \\
\text { Slight, } \\
\%\end{array}$ & $\begin{array}{l}\mathbf{5} \\
\text { Very } \\
\text { Slight, \% }\end{array}$ & $\begin{array}{l}\text { No } \\
\text { Response, } \\
\%\end{array}$ \\
\hline 1 & Land for mix uses & 69 & 22.2 & 0 & 0 & 8.8 & \\
\hline 2 & Fishing & 48 & 42.7 & 0 & 7.7 & 3.6 & \\
\hline 3 & Hunting & 11.5 & 38.7 & 23.8 & 9.4 & 6.5 & \\
\hline 4 & Timber Forest Products (TFP's) & 22 & 53.1 & 10.5 & 9.4 & 5 & \\
\hline 5 & $\begin{array}{l}\text { Non-Timber forests Products } \\
\text { (NTFP's) }\end{array}$ & 41.6 & 32.6 & - & 16.7 & 9 & \\
\hline 6 & Farming & 73 & 16.3 & 1.3 & 7.3 & 1.5 & \\
\hline 7 & Sand mining & 5.9 & 6.5 & 6.7 & 51.3 & 29.7 & - \\
\hline 8 & Cost of Living/ inflation & 76.6 & 23.4 & - & - & 10 & 1.5 \\
\hline 9 & Potable water supply & 32.4 & 50.8 & 3.6 & - & - & 1.7 \\
\hline 10 & Poverty level & 92.5 & 5.9 & - & 6.5 & - & 1.8 \\
\hline 11 & $\begin{array}{l}\text { Overall Social Environment } \\
\text { over time }\end{array}$ & 82.45 & 9.4 & - & & 1.7 \\
\hline
\end{tabular}

(Source:Ibama and Eyenghe, 2015)

The results of Nkaa, Amadi and Wegwu, (2017) on investigating the level of trace metals in drinking water in crude oil contaminated community in Gokana, Rivers State,
Nigeria, using Atomic Absorption Spectrophotometer were as follows:

Table 4: Investigating The Level Of Trace Metals In Drinking Water In Crude Oil Contaminated Community In Gokana, Rivers State, Nigeria

\begin{tabular}{|l|l|l|l|l|l|}
\hline .Heavy Metals Concentration, mg/kg & \multicolumn{1}{l|}{ Iron, Fe } \\
\hline Sites & Cobalt, Co & Zinc, Zn & $\begin{array}{l}\text { Magnesium, } \\
\text { Mg }\end{array}$ & Copper, Cu & \\
\hline Gbe & $0.77 \pm 0.02$ & $0.43 \pm 0.01$ & $0.57 \pm 0.02$ & $0.34 \pm 0.01$ & $0.67 \pm 0.03$ \\
\hline Kpor & $0.65 \pm 0.03$ & $0.12 \pm 0,01$ & $0.33 \pm 0.03$ & $0.42 \pm 0.01$ & $1.34 \pm 0.04$ \\
\hline Mogho & $0.75 \pm 0.02$ & $0.34 \pm 0.02$ & $0.64 \pm 0.02$ & $0.11 \pm 0.01$ & $1.28 \pm 0.02$ \\
\hline D-bere & $0.93 \pm 0.01$ & $0.22 \pm 0.02$ & $0.21 \pm 0.02$ & $0.31 \pm 0.02$ & $1.43 \pm 0.03$ \\
\hline K-Dere & $0.88 \pm 0.03$ & $0.32 \pm 0.03$ & $0.43 \pm 0.01$ & $0.27 \pm 0.01$ & $2.20 \pm 0.02$ \\
\hline Bodo City & $0.90 \pm 0.02$ & $0.52 \pm 0.02$ & $0.22 \pm 0.03$ & $0.21 \pm 0.01$ & $1.28 \pm 0.02$ \\
\hline
\end{tabular}

REARRANGING AND RE-ORGANIZING THE

WORK OF Nkaa, Amadi and Wegwu (2017) of Table 4.

\section{SAMPLES OF HEAVY METAL CONCENTRATIONS ON GBE SITE}

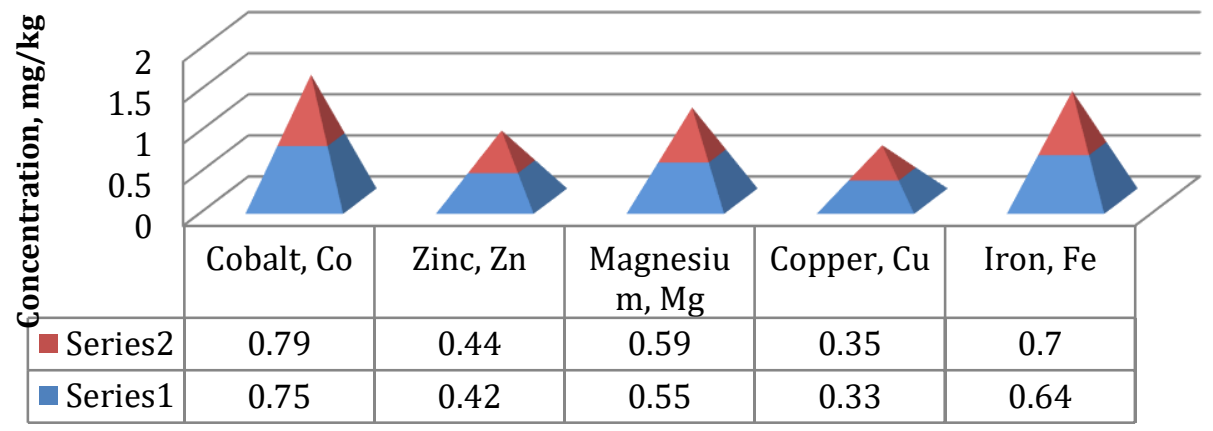

Figure 14: Samples of Heavy Metal Concentrations on Gbe Site 


\section{SAMPLES OF HEAVY METAL CONCENTRATIONS ON KPOR SITE}

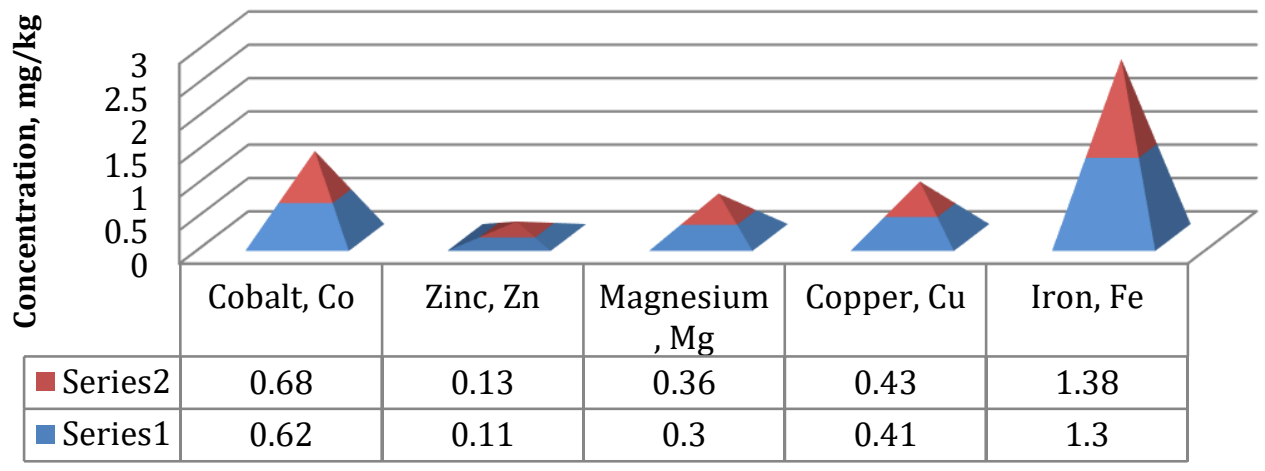

Figure 15: Samples of Heavy Metal Concentrations on Kpor Site

\section{SAMPLES OF HEAVY METAL CONCENTRATIONS ON MOGHO SITE}

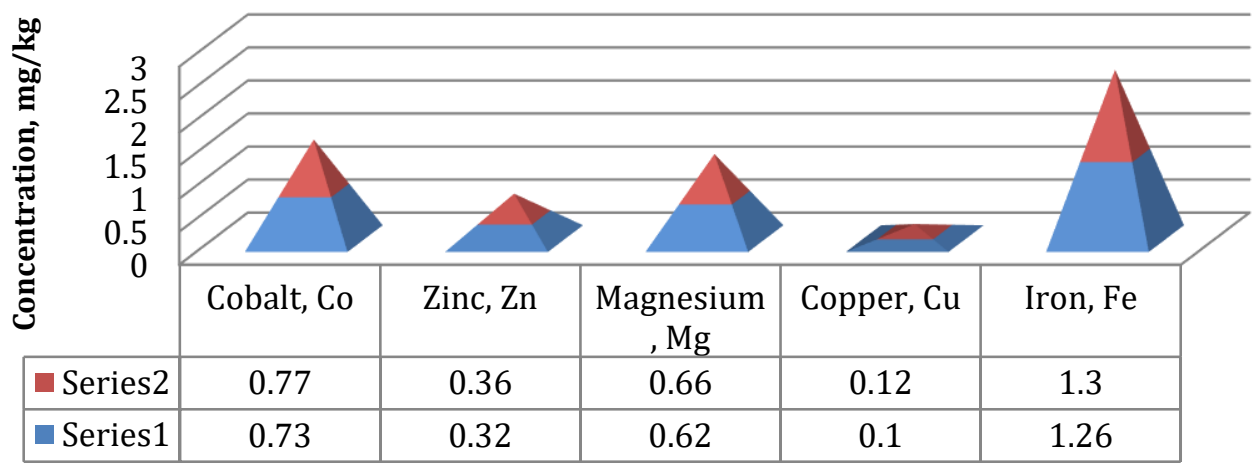

Figure 16: Samples of Heavy Metal Concentrations on Mogho Site

\section{SAMPLES OF HEAVY METAL CONCENTRATIONS ON D-BERE SITE}

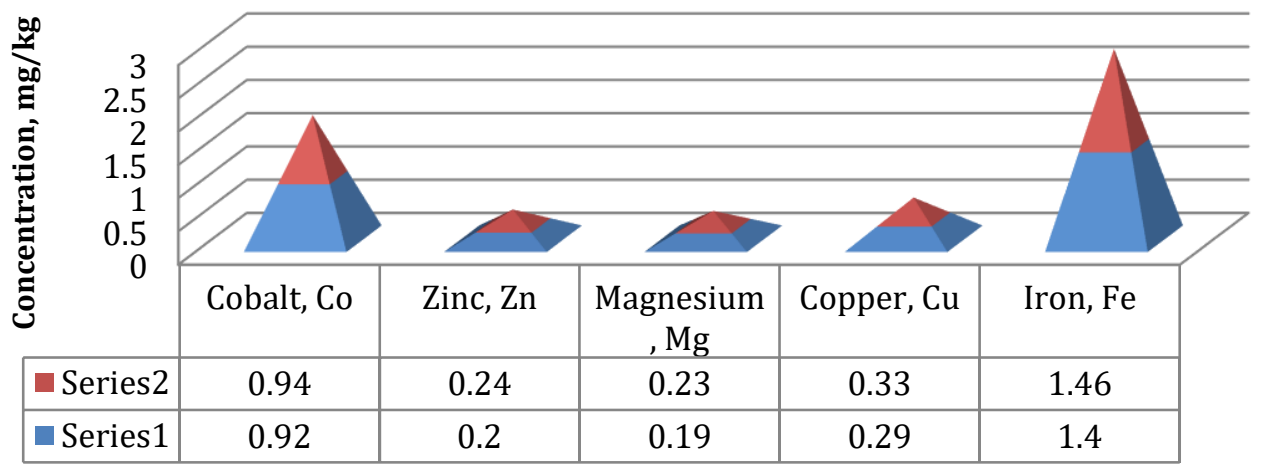

Figure 17: Samples of Heavy Metal Concentrations on D-Bere Site

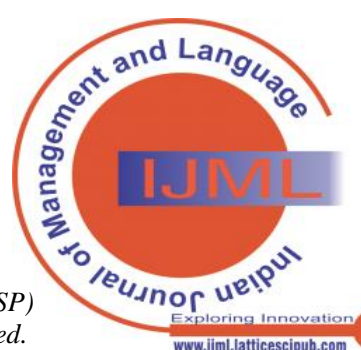




\section{SAMPLES OF HEAVY METAL CONCENTRATIONS ON K-DERE SITE}

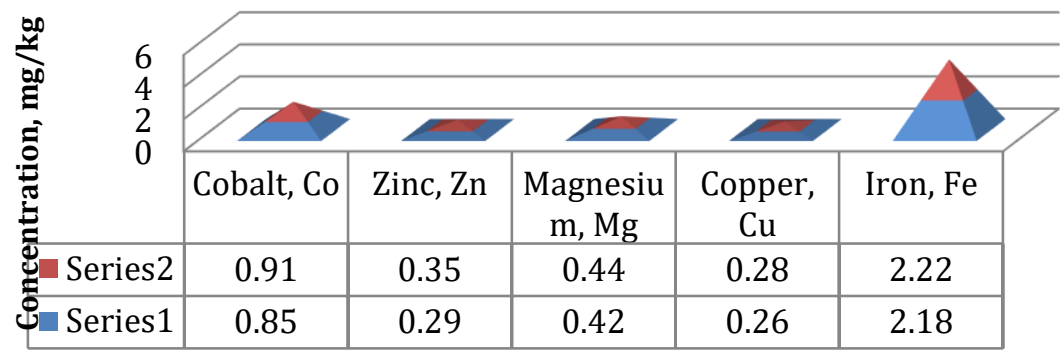

Figure 18: Samples of Heavy Metal Concentrations on K-Dere Site

\section{SAMPLES OF HEAVY METAL CONCENTRATIONS ON BODO CITY SITE}

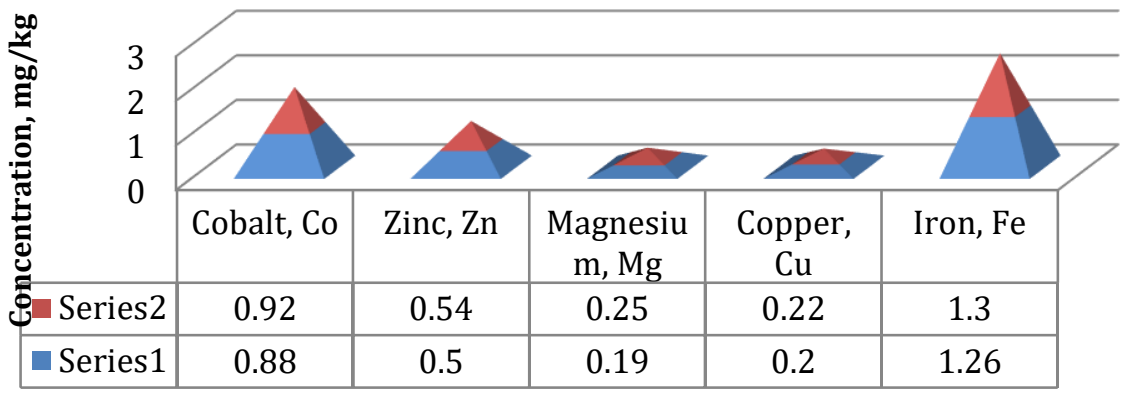

Figure 19: Samples of Heavy Metal Concentrations on Bodo City Site

Table 5: Quantity of Oil Spilled into the Niger Delta Region Annually From 1976 - 2014.

\begin{tabular}{|c|c|}
\hline Year of Spill Incidence & Estimated Quantity Of Oil Spilled (Barrel) \\
\hline 1976 & 20000 \\
\hline 1977 & 25000 \\
\hline 1978 & 490000 \\
\hline 1979 & 698000 \\
\hline 1980 & 600000 \\
\hline 1981 & 30000 \\
\hline 1982 & 30000 \\
\hline 1983 & 30000 \\
\hline 1984 & 30000 \\
\hline 1985 & 8000 \\
\hline 1986 & 75000 \\
\hline 1987 & 355000 \\
\hline 1988 & 15000 \\
\hline 1989 & 10000 \\
\hline & \\
\hline
\end{tabular}

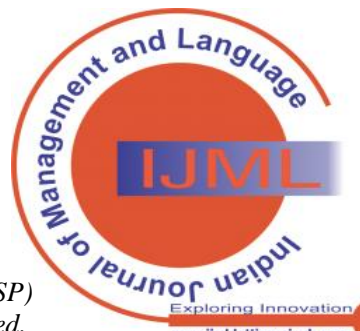


Consequence of oil and Waste Spills on the Environment of Ogoniland, Rivers State, Nigeria.

\begin{tabular}{|c|c|}
\hline 1990 & 18000 \\
\hline 1991 & 108000 \\
\hline 1992 & 50000 \\
\hline 1993 & 10000 \\
\hline 1994 & 35500 \\
\hline 1995 & 64000 \\
\hline 1996 & 45000 \\
\hline 1997 & 59500 \\
\hline 1998 & 99500 \\
\hline 1999 & 20000 \\
\hline 2000 & 30000 \\
\hline 2001 & 78500 \\
\hline 2002 & 20000 \\
\hline 2003 & 10000 \\
\hline 2004 & 9500 \\
\hline 2005 & 11500 \\
\hline 2006 & 20000 \\
\hline 2007 & 30000 \\
\hline 2008 & 100000 \\
\hline 2009 & 110000 \\
\hline 2010 & 18000 \\
\hline 2011 & 68500 \\
\hline 2012 & 18000 \\
\hline 2013 & 3550 \\
\hline 2014 & 10500 \\
\hline
\end{tabular}

(Source:Enegide and Chukwuma, 2018)

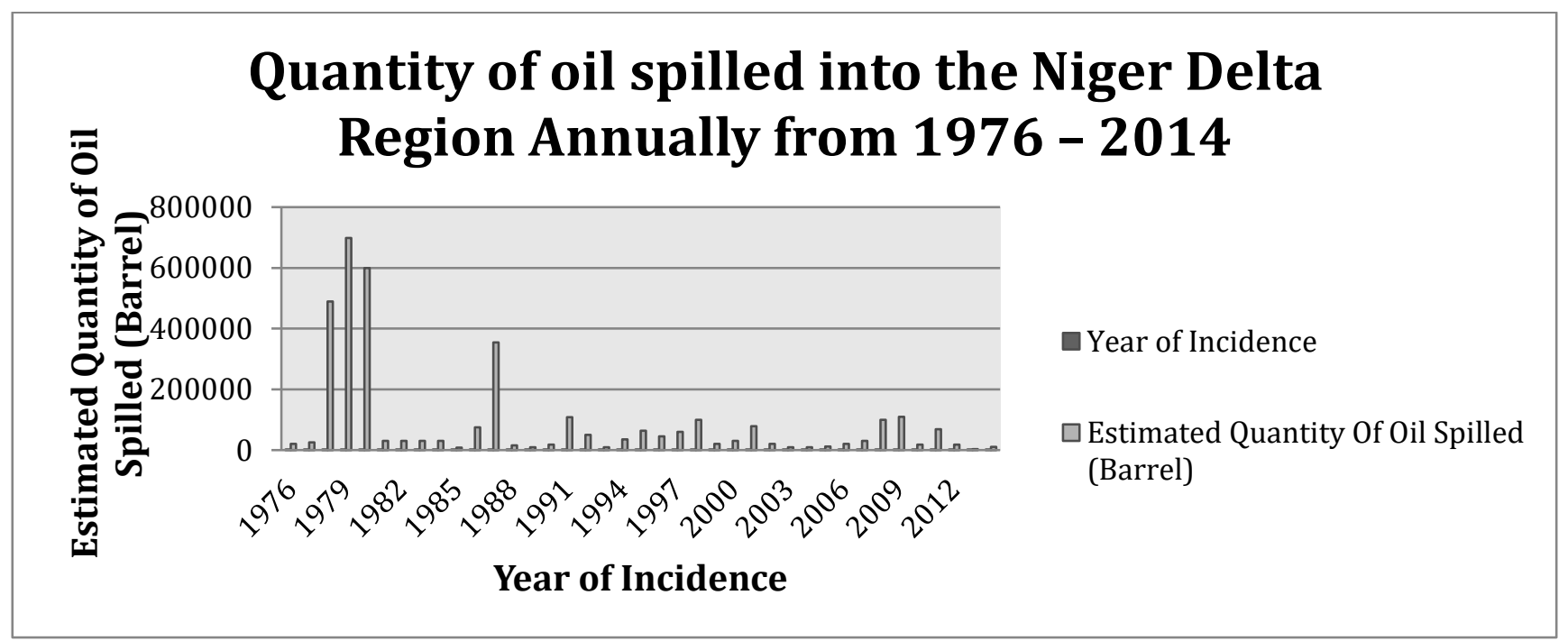

Figure 20: graph showing the quantity of oil Spillages into the Niger Delta Region annually from 1976 - 2014.

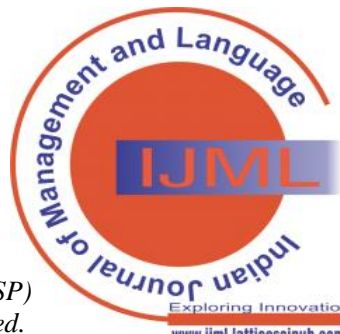




\section{RESULTS AND DISCUSSION}

In figure 10, the mean value of the Total Petroleum Hydrocarbon (TPH) was recorded in Biara community soil and water in Ogoniland. The same goes for the mean value of Polycyclic Aromatic Hydrocarbon (PAH) in which it had its highest value in Biara community soil and water in Ogoniland. Bodo was only contaminated on the average for both soil and water environment.In Figure 13, response given by people that were severely hit from spillage contamination by Shell operations was $44 \%$. On table 3, the impact of oil production had its worst toll in poverty increase on Ogoniland and on the severe case on forest vegetation.Other communities affected were recorded. In figure 14, Gbe community has cobalt as its highest metallic concentrate contaminant in spill. In figure 15, Kpor community has iron as its highest metallic concentrate contaminant in spill. The same was recorded for high Iron concentrate contaminant for Mogho in figure 16, D-bere in figure 17, K-Dere in figure 18 and Bodo city in figure 19.

In general perspective, the quantity of oil spillage recorded in the Niger-Delta in 1979 was 70,000barrel (seventy thousand barrel), as seen in figure 20. This was arrested and put under control until 1987 when the highest spill of 355,000 barrel was recorded in 1987. The spike of oil spillage graph has declined, but has also been fluctuating ever since.

\section{CONCLUSION AND RECOMMENDATIONS}

The major challenge in the Niger-Delta, especially Ogoniland part of Nigeria where production of Oil and Gas occurs is Oil and fuel spills. This causes serious risks and hazards to the ecosystem and environment. This has been widely shown by research carried out on some communities in Ogoniland using sample from different environment that are affected by spillages of oil and wastes. The spill contained contaminants like: Total Petroleum Hydrocarbon (TPH), Polycyclic Aromatic Hydrocarbon (PAH), Cobalt, Iron, Zinc, Magnesium and copper. This has left many animals, plants and men dead. These spills are caused by: natural causes, human, mysterious causes. Oil spills can be managed by enforcing laws and adopting policies like Oil pollution Act of 1990; Endangered Species Decree Cap 108 LFN 1990; Federal Environmental protection Agency Act Cap 131 LFN 1990; Harmful Waste Cap 165 LFN 1990; Petroleum (Drilling and Production) Regulations, 1969; Mineral Oil (Safety) Regulations, 1963; Associated Gas Re-injection Act 1979; International Convention on the Establishment of an International Fund for Compensation for Oil Pollution Damage, 1971; Convention on the Prevention of Marine pollution Damage, 1972; African Convention on the Conservation of Nature and Natural Resources,1968; International Convention on the Establishment of an International Fund for the compensation for Oil Pollution Damage, 1971; The Environmental Impact Assessment (EIA) Decree No 86 of 1992 and The Oil pipelines Act Cap 145 LFN 1990.

\section{REFERENCES}

1. Alexandra Gas and Oil Connections, (2006): Nigeria Forms Oil Spill Detection Agency.

2. Arisukwu O. C. and Kennedy C. N. (2012): Shell Petroleum Development Corporation Oil Exploration And Socio-Economic Life
In Ogoni, Nigeria; Department Of Sociology, University Of Ibadan, Journal of Sustainable Development in Africa ,Volume 14, 132 - 140.

3. Akpomuvie O. B. (2011): Tragedy Of Commons: Analysis of Oil Spillage, Gas Flaring and Sustainable Development of the Niger Delta Of Nigeria; Delta State University, Sociology Department, Delta State, Nigeria; Journal Of Sustainable Development Vol. 4, No. 2, 200-210. [CrossRef]

4. Aghalino S. O. and EyinlaB.(2009): Oil Exploitation and Marine Pollution - Evidence from the Niger Delta, Nigeria; Department of History, Faculty of Arts, University of Ilorin, J Hum Ecol, 28(3): 177182. [CrossRef]

5. Akachi O. (2011): Social Consequences of Environmental Change in the Niger Delta Of Nigeria, Department of History and International relation; Journal of Sustainable Development, Vol. 4, No. 2, 123 -135. [CrossRef]

6. Amnesty International. (2009). Nigeria: Petroleum, Pollution And Poverty In The Niger-Delta.

7. Christopher B., Obida., Blackburn J., Duncan W.K. and semple T. (2017): Quantifying the Exposure of Humans and Environment To Oil Pollution In The Niger Delta Using Advanced Geostatistical Techniques; Environment International Journal;

8. Corporate Social Responsibility (CSR) in Niger Delta Region - The Need for a Prygmatic Approach, department of Economics, Delta State University, Abraka; Journal of Social Science and Public Policy, Volume 4, 1-21.

9. DPR (2007): Department of Petroleum Resources of Nigeria; Oil Spill Data.

10. Dr.TombariB.(2018): Community Understanding Of The Environmental And Socio-Economic Consequences Of Petroleum Exploitation In Ogoni, Rivers State, Nigeria; Department of Geography and Natural Resource Management, University of Uyo, Uyo, Akwa Ibom State, Nigeria, International Journal of Advanced Research and Publications, Volume 2 Issue 11, 51-55.

11. Dr. Ibaba S. I. (2010): Environmental Protection Laws and Sustainable Development in the Niger Delta; Africana, 45 - 77.

12. Enegide C., Chukwuma K.C. (2018): Oil Spillage and Heavy Metals Toxicity Risk in the Niger Delta, Nigeria; Journal of Health and Pollution, Vol. 8, No. 19, 1-8. [CrossRef]

13. Emoyan O. O., Akpoborie I. A. and Akporhonor E. E. (2008): The Oil And Gas Industry and The Niger Delta - Implications For The Environment, Delta State University, Abraka Nigeria; J. Appl. Sci. Environ. Manage, Vol. 12(3) 29 - 37.

14. Gabriel K. B. (2013): Emerging Issues in Compensation Valuation for Oil Spillage in the Niger Delta Area of Nigeria, Department of Estate Management, University of Lagos, Nigeria ;Journal of Reviews on Global Economics, 2, 31-45.

15. Hoff, R., (1993): Bioremediation - An Overview of its Development and use for Oil Spill Clean-Up; 26, 476 - 481. [CrossRef]

16. Ibama B. and Eyenghe T. (2015): An Evaluation Of The Effects Of Petroleum Exploration and Production Activities On The Social Environment In Ogoni Land, Nigeria; International Journal Of Scientific \& Technology Research, Volume 4, Issue 04, 273 - 282.

17. Ite A. E. and Ibok U. J. (2013): Gas Flaring and Venting Associated with Petroleum Exploration and Production in the Nigeria's Niger Delta American Journal of Environmental Protection, 1 (4). 70 - 77. [CrossRef]

18. Kponee K. Z. Et al, (2015): Petroleum contaminated water and health symptoms: a Cross-sectional pilot study in a rural Nigerian community, Environmental Health, 14 - 86. [CrossRef]

19. Kelly E., Zephaniah O.E., Lucky A. and Jonathan S. (2012) Environmental Issues and Corporate Social Responsibility (CSR) in Niger delta Region - The Need for Prigmatic Approach, Department of Environmental Management Anambra State University; Journal of Social Science and Public Policy, Volume 4, 1-21.

20. Mmom P. and Igbuku A. (2015): Challenges and prospect of environmental Remediation/Restoration in Niger Delta of Nigeria The case of Ogoniland ; Journal of energy technologies and Policy, 5 (1) Pages 5-10.

21. Mmon P. and Igbuku A. (2015): Challenges and prospect of environmental restoration in Niger Delta of Nigeria: The case of Ogoniland; Journal of Energy Technologies and Policy; 5(1):12-20.

22. Neff, J. M. (2002): Bioaccumulation in marine organisms - Effect of contaminants from oil Well produced water, Elsevier, 2, pp. 26-28. [CrossRef]

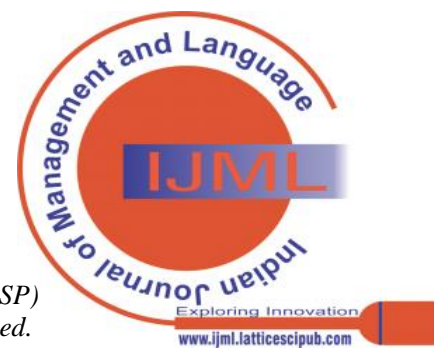


23. Nkaa K.W., Amadi B.A. and Wegwu M.O. (2017): Trace Elements Levels in Drinking Water from Gokana, Ogoniland, River State, Nigeria; International Journal of Hydrology, Volume 1, Issue 2,55-57. [CrossRef]

24. Odoemene, A. (2011): Social Consequences of Environmental Change in the Niger Delta of Nigeria. Journal of Sustainable Development, 4(2), 123-135. [CrossRef]

25. Ogidi O.I. and Njoku O.C.(2017): A Review on the Possibilities of the Application of Bioremediation Methods in the Oil Spill Clean-Up of Ogoni Land , Department of Science Laboratory Technology, Federal Polytechnic, Ekowe, Bayelsa State, Nigeria ; International Journal of Biological Sciences and Technology, Volume 9, Issue 6, 4859.

26. Ophori D. U. (2006): A Preliminary Analysis of Regional Groundwater Movement in the Niger Delta, Nigeria, Journal of Environmental Systems, 32 (2). 125 - 144. [CrossRef]

27. Pittock, J. et al,(2108): Managing threats in freshwater systems within protected area In Conservation and Management, Taylor and Francis, Oxford UK, pp. 84 - 109. [CrossRef]

28. Tombari B. (2019): Deep Issues behind the Crisis in the Niger Delta Region - The Case of Oil Exploration in Ogoniland, Rivers State, Nigeria; Department of Geography and Natural Resources Management, Faculty of Social Science, University of Uyo, Uyo, Akwa Ibom State, Nigeria; Asian Journal of Geographical Research, 2(1), 1-12, 2019. [CrossRef]

29. Thomas A. I. (2004): Conflict in Niger Delta - A Unique Case or a Model for Future Conflicts in Other Oil-Producing Countries; Oil Policy in the Gulf Of Guinea, $101-115$.

30. UNEP (United Nations Environmental Program) - (2013): Environmental Assessment of Ogoniland - Background Environmental Degradation in Ogoniland, 2013.

31. UNEP (United Nations Environmental Program) - (2011): Gelology of Ogoniland ; Ogoni Fact Sheet.

32. Victoria C .I.(2013): Effects Of Fossil Fuel Extraction On Gokana Environment, Ogoniland, Nigeria; 2nd International Conference on Energy Systems and Technologies, Cairo, Egypt.

\section{AUTHOR PROFILE}

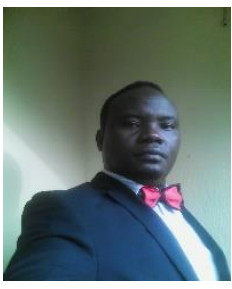

Mining Engineer, Amosu Cyril Olumuyiwa Professional background:

- $\quad$ Lecturer and researcher at Yaba College of Technology, Lagos, Nigeria.

- Associate Environmental Professionals (AEP), National registry Of Environmental Professionals (NREP). Nigeria (COREN).

- Council for Regulation of Engineering in

Education:

- $\quad$ Master of Engineering (M. Eng.) in Mining Engineering from Federal University of Technology Akure, Nigeria (2019 - Date).

- Masters (M. Sc.) in Petroleum Engineering and Project Development (2004 - 2005).

- $\quad$ Bachelors of Engineering (B. Eng.) in Mining Engineering from Federal University of Technology Akure, Nigeria (1995 - 2001).

Previous publishing experience

About fifteen (15) journals and conference published already with different publishers which can be found on Google Scholar, ResearchGate, Publon and Orcid. These journals captures Mining and Petroleum.

Personal details:

Married with three (3) children; lives in Lagos state, Nigeria; Personal interest is writing and research.

Contact information:

Personal E-mail: muyixx1zillion@gmail.com

Official E-mail: Cyril.amosu@yabatech.edu.ng

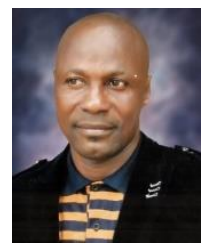

Dr. Tunde A. Adeosun

Professional background:

- $\quad$ Chief lecturer and researcher at Yaba College of Technology, Lagos, Nigeria.

Nigeria (COREN)

Position

- $\quad$ Nigeria Society of Engineers (NSE)

Head of Department, (2015- 2017)

Department of Mineral \& Petroleum Engineering, School of Engineering, Yaba College of Technology

\section{Education:}

Ph.D. Applied Mathematics (Petroleum and Geosystems) (2011 - 2019)

M.Tech. Applied Geophysics (Geosystems Mathematics) $\quad$ (2008 - 2010)

PGD. Applied Geophysic

$(2000-2004)$

M.Sc. Petroleum Engineering (Reservoir Simulation ) (2007 - 2009)

PGD. Petroleum Engineering

M.Sc. Applied Mathematics (Fluid Flow in Porous Media) (2004 - 2007)

B.Sc. (Hons) Mathematics (1990 - 1995)

\section{Previous publishing experience}

More than (25) journals published already with different publishers which can be found on Google Scholar, ResearchGate, etc. These journals capture Mathematics, Petroleum, geophysics, Geology, Geosystems, etc.

Personal details:

Married with three (3) children; lives in Lagos state, Nigeria; Personal interest is writing and research.

Contact information:

Personal E-mail: adebaba2001@yahoo.com

Official E-mail: tunde.adeosun@yabatech.edu.ng

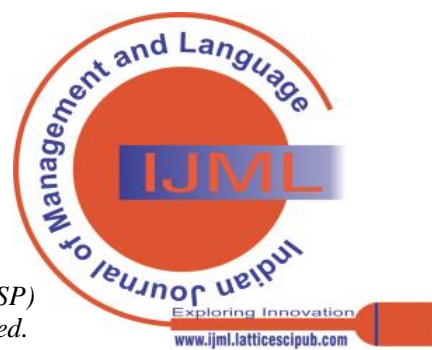

